\title{
INTEGRATION OF FOREST INDUSTRIES ${ }^{1}$
}

\author{
BY J. G. SOMERS
}

\author{
Manitoba Forest Service, Winnipeg, Manitoba
}

W

HEN considering the question - "In any integration of forest industries what is the dividing line in the allocation of softwoods as sawlogs and pulpwood material?" - it is obvious that there is no single clear-cut answer satisfactorily applicable to all areas and conditions found across the Dominion. No attempt will be made in this paper, therefore, to provide all the answers, but rather to explain briefly some of the practices carried out and experiences obtained in recent years in Manitoba which may be found useful as a basis for discussion.

Up to the early years of World War II timber extraction in Manitoba, as in other parts of the Dominion, was carried out almost entirely by single purpose operations. There were lumber operators who cut only sawlogs, pulpwood operators who cut only pulpwood, and railway tie operators who cut only railway ties, etc. Early in the war, however, because of an increased demand for forest products of all kinds, we took advantage of the opportunity offered and instituted a gradual swing away from single purpose operations, adopting instead, insofar as conditions would allow, a policy requiring integration of operations. This policy was adopted in order to conserve forest resources.

On the whole the results attained have been very gratifying, both from the point of view of the operator, who has benefitted from a greater return for money spent on improvements in the way of roads, camps, etc., and from the point of view of the administration. As an illustration I may say that our forest revenue in Manitoba has more than doubled during the past five years, not as the result of an increase in the rate of timber dues-our dues schedule is the same now as before the war-nor because of increased forest depletion, but largely as the result of more intelligent utilization, less waste in the woods, and a larger yield per acre made possible by integrated operations. Generally speaking, and from the long term point of view particularly, there can be no question but that integrated operations pay. In making a swing away from single purpose operations it may be said that we in Manitoba are in a better position to do so than some of the other provinces insofar as utilization of softwoods for lumber and pulpwood is concerned. No long term holdings have been disposed of in the province since the natural resources were taken over in 1930. We are, therefore, bound by a very minimum of long term agreements, the drafting of which invariably contemplated single purpose operations only and the production of a single product.

Our principal sawlog and pulpwood species in Manitoba are white spruce and black spruce, between which there is a pretty well defined line as regards rate of growth, size and suitability for one product or the other. In the disposal of these species our policy has been, except

1. Paper presented at the fortieth annual meeting of the Canadian Society of Forest Engineers, Fredericton, N.B., October 4 to $7,1948$. 
under special conditions, "that no white spruce shall be made into pulpwood, but shall be utilized as lumber or boxwood". The diameter range of black spruce, which rarely exceeds 12 inches D.B.H., and which is particularly suitable for newsprint, precluded the possibility that much of it would be utilized as sawlogs. In addition to a rather well defined line as to the suitability of the two species for different products, the two species are not commonly found growing in mixture with each other, the black spruce being found for the most part on the lower ground, and the white spruce on the higher ground, the inter-mixture of the two species being found chiefly on the edges of stands where one type merges into the other.

It will be seen, therefore, that starting integrated operations in Manitoba was a comparatively simple matter, and in some instances only required supervision of sale agreements, (where sawlogs were the principal product black spruce was to be cut at the same time as the sawlogs and utilized as pulpwood; and where pulpwood was the principal product white spruce was to be cut and utilized as lumber).

Many instances have arisen, however, where for various reasons such as susceptibility to wind-throw, insect attack, poor growing site, or dedication of the land for agricultural purposes, it has been desirable to cut white spruce to a lower diameter than could economically be used as sawlogs. The question then arises, and it is the question with which we are most concerned at the moment, as to what trees or portions of trees should go into pulpwood. If we were considering this question purely from the point of view of utilization, finding an answer would be a fairly simple matter. At this point, however, a great number of variables enter into the picture, making it necessary to consider each individual area or concession pretty much on its own merits.

First of all, if the area to be logged is primarily a pulpwood area, that is to say, if a large portion of the timber to be cut is comprised of trees smaller than those commonly considered suitable for sawlogs, are there sufficient trees of sawlog size to make a sawlog operation economically practical? Will it be necessary to establish a sawmill, or can the logs be transported economically to a mill already established? If the area under consideration is primarily a sawlog proposition from the point of view of "size of timber to be cut" and "its suitability for lumber", we must consider whether there is a sufficient cordage per acre made up of trees or portions of trees of less than sawlog size to be removed to make removal as pulpwood economically practical.

If it is a borderline area the question arises, would raising the diameter limit tentatively set for pulpwood for the purpose of study permit of a pulpwood operation? And if this were done, what effect would it have on the utilization of the larger trees as sawlogs? Would a sawlog operation then be a practical proposition?

In the allocation of timber as sawlogs and pulpwood material consideration must also be given to demand, market prices and domestic needs. 
TABLE I

Part (a)

\begin{tabular}{|c|c|c|c|c|c|c|}
\hline \multirow{2}{*}{$\begin{array}{c}\text { D.B.H. } \\
\text { in } \\
\text { Inches }\end{array}$} & \multirow{2}{*}{$\begin{array}{c}\text { Total Vol. } \\
\text { in } \\
\text { Cu. Ft. } \\
\text { including } \\
\text { bark }\end{array}$} & \multicolumn{2}{|c|}{$\begin{array}{l}\text { Yolume incl. bark utiliz- } \\
\text { ed ag cordwood down to } \\
\text { a top diameter } 3^{\prime \prime}\end{array}$} & \multicolumn{3}{|c|}{$\begin{array}{l}\text { Trees utilized as Rough Lamber down } \\
\text { to a top diameter of } 5 \text { " inside bark }\end{array}$} \\
\hline & & $\begin{array}{l}\text { in } \\
\text { Cords }\end{array}$ & $\begin{array}{l}\text { Percentage } \\
\text { of total vol. } \\
\text { incl. bark. } \\
\text { atilized }\end{array}$ & in & $\begin{array}{c}\text { in Cu. Ft. } \\
\text { without } \\
\text { bark }\end{array}$ & $\begin{array}{l}\text { Percentage } \\
\text { of total } \\
\text { volume inel. } \\
\text { bark utilized }\end{array}$ \\
\hline 6 & 4.24 & 0.034 & 80 & 5 & 0.4167 & 9.8 \\
\hline 7 & 6.04 & 0.052 & 90 & 15 & 1.2500 & 20.7 \\
\hline 8 & 8.62 & 0.082 & 92 & 30 & 2.5000 & 29.0 \\
\hline 9 & 11.87 & 0.115 & 93 & 47 & 3.9167 & 33.0 \\
\hline 10 & 15.56 & 0.151 & 94 & 62 & 5.1667 & 33.2 \\
\hline 11 & 19.35 & 0.180 & 95 & 82 & 6.8333 & 35.3 \\
\hline 12 & 24.43 & 0.235 & 96 & 115 & 9.5833 & 39.2 \\
\hline 13 & 29.70 & 0.290 & 96 & 142 & 11.8333 & 39.8 \\
\hline 14 & 35.48 & 0.346 & 96 & 175 & 14.5833 & 41.1 \\
\hline 15 & 41.72 & 0.403 & 96 & 210 & 17.5000 & 42.0 \\
\hline 16 & 48.70 & 0.469 & 96 & 260 & 21.6667 & 44.5 \\
\hline 17 & 56.58 & 0.554 & 96 & 302 & 25.1667 & 44.5 \\
\hline 18 & 65.02 & 0.647 & 96 & 355 & 29.5833 & 45.5 \\
\hline 19 & 73.40 & 0.744 & 96 & 406 & 33.8333 & 46.1 \\
\hline 20 & 82.76 & 0.837 & 96 & 473 & 39.4167 & 47.6 \\
\hline 21 & 93.49 & 0.930 & 96 & 532 & 44.3333 & 47.5 \\
\hline 22 & 104.33 & 1.030 & 96 & 602 & 50.1667 & 48.1 \\
\hline 23 & 114.23 & 1.123 & 96 & 677 & 56.4167 & 49.3 \\
\hline 24 & 125.62 & 1.228 & 96 & 755 & 62.9167 & 50.1 \\
\hline
\end{tabular}

Part (b)

\begin{tabular}{rl|l|c|c|c}
\hline \multicolumn{2}{l}{$\begin{array}{l}\text { Trees utilized down to a top diameter of } \\
\text { balance as cordwood, in a combined operation of Sawlogs and }\end{array}$} \\
\hline
\end{tabular}




\section{TABLE I}

Part (c)

Trees aitilized down to a top diameter of $3^{\prime \prime}$, as lumber down to a top diameter of $7^{\prime \prime}$ to $8^{\prime \prime}$ and balance as cordwood in a combined operation of Sawlogg and Pulpwood.

\begin{tabular}{|c|c|c|c|c|c|}
\hline \multicolumn{2}{|c|}{ Rough Lumber } & \multicolumn{2}{|c|}{ Rough Palpwood } & \multirow{2}{*}{$\begin{array}{l}\text { Total Vol. } \\
\text { in } \\
\text { Cu. Ft. } \\
\text { Utilized }\end{array}$} & \multirow{2}{*}{$\begin{array}{c}\text { Percentage } \\
\text { of total vol. } \\
\text { incl. bark } \\
\text { utilized }\end{array}$} \\
\hline F.B.M. & Cu. Ft. & Cords & Cu. Ft. & & \\
\hline Nil & Nil & 0.034 & 3.39 & 3.39 & 80 \\
\hline Nil & Nil & 0.052 & 5.44 & 5.44 & 90 \\
\hline 10 & 0.83 & 0.050 & 4.25 & 5.08 & 60 \\
\hline 30 & 2.50 & 0.044 & 3.74 & 6.24 & 52.5 \\
\hline 55 & 4.58 & 0.041 & 3.49 & 8.07 & 51.8 \\
\hline 75 & 6.25 & 0.039 & 3.32 & 9.57 & 49.4 \\
\hline 105 & 8.75 & 0.037 & 3.15 & 11.90 & 48.7 \\
\hline 132 & 11.00 & 0.036 & 3.06 & 14.06 & 47.4 \\
\hline 170 & 14.17 & 0.036 & 3.06 & 17.23 & 48.5 \\
\hline 205 & 17.08 & 0.036 & 3.06 & 20.14 & 48.3 \\
\hline 250 & 20.83 & 0.036 & 3.06 & 23.89 & 49.0 \\
\hline 295 & 24.58 & 0.036 & 3.06 & 27.64 & 49.0 \\
\hline 345 & 28.75 & 0.036 & 3.06 & 31.81 & 49.0 \\
\hline 400 & 33.33 & 0.036 & 3.06 & 36.39 & 50.0 \\
\hline 460 & 38.33 & 0.035 & 2.98 & 41.31 & 50.0 \\
\hline 525 & 43.75 & 0.035 & 2.98 & 46.73 & 50.0 \\
\hline 595 & 49.58 & 0.035 & 2.98 & $\because 2.56$ & 50.3 \\
\hline 670 & 55.83 & 0.035 & 2.98 & 58.81 & 51.4 \\
\hline 745 & 62.08 & 0.035 & 2.98 & 65.06 & 51.8 \\
\hline
\end{tabular}

These tabulations are based on taper curves and volume tables constructed on the basis of the measurement of approximately 500 trees. All the basic figures were smoothed out by curves. In the cases of combined operations of pulpwood and sawlogs, one cord of pulpwood produced from the tops is considered to contain 85 cubic feet of rough wood.

We must consider, for instance, what industries, local or otherwise, must be supported and to what extent, if any, should utilization be sacrificed in order to support them. Money return for the products produced must always be a major consideration; at the same time the more we can utilize of our raw material the better, and utilization, therefore, will always be a determining factor in drawing the dividing line.

Having in mind the desirability of expanding our policy of integrated operations, two preliminary studies have been carried out in Manitoba. The first of these, based on volume tables and taper curves for white and black spruce on an area around the Duck Mountain Forest Reserve in Manitoba, is presented in tabular form and is designated as Tables No. $I$ and II. The second, presented as Table No. III, deals with an area which, a short time ago, we had under consideration for a timber sale, and which supported an estimated volume of $1,550,571$ cubic feet of white and black spruce. These tables will be reviewed very briefly below. 
Table No. I, which is divided into Parts (a), (b), and (c), attempts to show theoretically the percentage of total volume which might be utilized from trees of different diameters, ranging from 6 inches to 24 inches D.B.H., (a) a comparison if used as pulpwood only, or if used as sawlogs only; (b) if used as sawlogs down to a top diameter of 5 inches, balance as pulpwood to 3 inches; and (c) if used as sawlogs to a top diameter of 7 to 8 inches, and the balance to 3 inches as pulpwood. In the computation of these data stump height was considered as 12 inches, cord 128 cubic feet of rough wood, feet board measure by International Log Rule " $1 / 4^{-i n c h ~ K e r f ", ~ t r i m m i n g ~ a l l o w a n c e ~ o n ~ s a w l o g s ~} 4$ inches.

Briefly, part (a) of Table No. I shows that, in use as pulpwood, utilization ranges from 80 per cent in case of trees 6 inches D.B.H. up to 96 per cent in the case of trees 24 inches D.B.H., as against 9.8 per cent to 50.1 per cent respectively if utilized as rough lumber.

Part (b) of Table No. I contemplates utilization of trees or portions of trees down to a top diameter of 5 inches as sawlogs, and the balance down to a top diameter of 3 inches as pulpwood. On this basis utilization is shown as being 37 per cent in the case of trees 6 inches D.B.H., ranging progressively upwards to 50.4 per cent in the case of trees 24 inches D.B.H.

Part (c) of Table No. I contemplates utilization of trees down to a top diameter of from 7 to 8 inches as sawlogs and the balance down to a 3-inch top as pulpwood, and shows utilization as 80 per cent, 73 per cent, and 60 per cent respectively for trees in the 6-inch, 7-inch, and 8-inch diameter class, with utilization of trees of the higher classes (9 inches D.B.H. to 24 inches D.B.H.) ranging from a low 47.4 per cent to a high of 52.5 per cent. It is obvious, of course, that the greater the portion of the tree utilized as pulpwood, regardless of diameter, the greater will be the utilization of raw material, and the whole subject pretty well boils down to the question, "To what extent should we sacrifice utilization in consideration of money return and the other factors involved?".

Table No. II is divided into Parts (a) and (b). Part (a) shows the revenue return, based on the regulation rate of dues on spruce in Manitoba, namely, $\$ 1.50$ per cord for pulpwood and $\$ 4.00$ per thousand feet board measure (International Log Rule) for lumber, and indicates a considerably greater return for trees 9 inches and over D.B.H. if completely used as lumber than if completely used as pulpwood, with only a rather insignifcant increase in the return in dues if a combined operation is contemplated, using the larger sections of trees as lumber and the small sections as pulpwood. For trees 9 inches and under utilization as pulpwood gives the greatest return.

Part (b) of Table No. II shows the return to the operator for trees of different diameters if utilized only as pulpwood and if utilized only as lumber; also, with respect to utilization in a combined operation, on the basis of $\$ 12.00$ per cord for pulpwood and $\$ 45.00$ per thousand for rough lumber, prices presently current in Manitoba f.o.b. car at rail head. The 
table shows a greater return for trees in the higher diameter classes if made into lumber than if made into pulpwood. This, of course, is partly the result of increased value added to the product by more complete manufacture, a factor which must be taken into account.

Table No. III deals with an area supporting an estimated 1,550,571 cubic feet of white and black spruce, and contemplates an operation utilizing white spruce down to a stump diameter of 12 inches and black spruce down to a stump diameter of 7 inches. It attempts to show, theoretically, the gross return to the operator on the basis of $\$ 12.00$ per cord for pulpwood and/or $\$ 45.00$ per thousand for rough lumber f.o.b. car at rail head; also the stumpage value on the basis of $\$ 1.50$ per cord for pulpwood and/or $\$ 4.00$ per thousand feet board measure for lumber. The following is a brief summary of the tabulation:

Product

As Lumber only to 5-inch top

As Pulpwood only to 3 -inch top...

As Lumber to top diameter 7 to 8 in., balance as Pulpwood to top diameter 3 in.

$\begin{array}{cr}\text { Amount Utilized } & \begin{array}{r}\text { Sale Value } \\ 22.6 \%\end{array} \\ \$ 189,765 \\ 86 \% & \$ 167,556 \\ 52.5 \% & \$ 236,193\end{array}$

Dues $\$ 16,868.00$ $\$ 20,944.50$ $\$ 24,205.50$

TABLE NO. II

Part (a)

\begin{tabular}{|c|c|c|c|c|}
\hline \multirow[b]{2}{*}{$\begin{array}{c}\text { D.B.H. } \\
\text { in } \\
\text { Inches }\end{array}$} & \multicolumn{4}{|c|}{$\begin{array}{l}\text { Stumpage values of spruce trees of various diameters } \\
\text { based on } \$ 4.00 \text { per M.F.B.M. for lumber and } \$ 1.50 \\
\text { per cord as pulpwood. }\end{array}$} \\
\hline & $\begin{array}{l}\text { Pulpwood } \\
\text { Value } \\
\text { in } \\
\$\end{array}$ & $\begin{array}{c}\text { Lumber down } \\
\text { to a } \\
\text { top diameter } \\
\text { of } 5^{\prime \prime} \\
\$\end{array}$ & $\begin{array}{l}\text { Lumber down to a } \\
\text { top diameter of } \\
5^{\prime \prime} \text { and balance } \\
\text { down to a top. } \\
\text { diameter of } 3^{\prime \prime} \\
\text { as pulpwood } \\
\$\end{array}$ & $\begin{array}{l}\text { Lumber down to } \\
\text { a top diameter } \\
\text { of } 7^{\prime \prime} \text { to } 8 \text { " and } \\
\text { balance down to } \\
\text { a top diameter } \\
\text { of } 3^{\prime \prime} \text { as palpwood } \\
\text { \$ }\end{array}$ \\
\hline & & & & as \\
\hline $\begin{array}{l}6 \\
7\end{array}$ & $\begin{array}{l}0.05 \\
0.08\end{array}$ & 0.02 & 0.08 & 0.08 \\
\hline 8 & 0.12 & 0.12 & 0.14 & 0.12 \\
\hline 9 & 0.18 & 0.19 & 0.20 & 0.19 \\
\hline 10 & 0.23 & 0.25 & 0.27 & 0.28 \\
\hline 11 & 0.27 & 0.33 & 0.35 & 0.36 \\
\hline 12 & 0.35 & 0.46 & 0.48 & 0.48 \\
\hline 13 & 0.44 & 0.57 & 0.58 & 0.58 \\
\hline 14 & 0.52 & 0.70 & 0.71 & 0.73 \\
\hline 15 & 0.61 & 0.84 & 0.85 & 0.87 \\
\hline 16 & 0.70 & 1.04 & 1.05 & 1.05 \\
\hline 17 & 0.83 & 1.21 & 1.22 & 1.23 \\
\hline 18 & 0.97 & 1.42 & 1.43 & 1.43 \\
\hline 19 & 1.12 & 1.62 & 1.63 & 1.65 \\
\hline 20 & 1.26 & 1.89 & 1.90 & 1.89 \\
\hline 21 & 1.39 & 2.15 & 2.14 & 2.15 \\
\hline 22 & 1.56 & 2.41 & 2.42 & 2.43 \\
\hline 23 & 1.68 & 2.71 & 2.72 & 2.73 \\
\hline 24 & 1.84 & 3.02 & 3.03 & 3.03 \\
\hline
\end{tabular}


INTEGRATED UTILIZATION — SOMERS

TABLE NO. II

Part (b)

\begin{tabular}{|c|c|c|c|c|}
\hline \multirow[b]{2}{*}{$\begin{array}{l}\text { D.B.H. } \\
\text { in } \\
\text { Inches }\end{array}$} & \multicolumn{4}{|c|}{$\begin{array}{l}\text { Sale Value of Spruce trees of various diameters based } \\
\text { on } \$ 45.00 \text { per } M \text {. for rough lumber and } \$ 12.00 \text { per } \\
\text { cord for pulpwood. }\end{array}$} \\
\hline & $\begin{array}{c}\text { Pulpwood } \\
\text { Value } \\
\text { in } \\
\$\end{array}$ & $\begin{array}{c}\text { Lumber } \\
\text { to } 5^{\prime \prime} \\
\text { top diameter } \\
\$\end{array}$ & $\begin{array}{l}\text { Lamber to } 5^{\prime \prime} \\
\text { Pulp. to } 3 " \\
\$\end{array}$ & $\begin{array}{c}\text { Lumber to } \\
7 " \text { - }^{\prime \prime} \\
\text { Pulp. to } 3^{\prime \prime} \\
\$\end{array}$ \\
\hline $\begin{array}{r}6 \\
7 \\
8 \\
9 \\
10 \\
11 \\
12 \\
13 \\
14 \\
15 \\
16 \\
17 \\
18 \\
19 \\
20 \\
21 \\
22 \\
23 \\
24\end{array}$ & $\begin{array}{r}0.40 \\
0.62 \\
0.98 \\
1.38 \\
1.81 \\
2.16 \\
2.82 \\
3.48 \\
4.15 \\
4.83 \\
5.60 \\
6.64 \\
7.76 \\
8.93 \\
10.04 \\
11.60 \\
12.36 \\
13.48 \\
14.74\end{array}$ & $\begin{array}{r}0.22 \\
0.67 \\
1.35 \\
2.11 \\
2.79 \\
3.69 \\
5.17 \\
6.39 \\
7.87 \\
9.45 \\
11.70 \\
13.59 \\
15.97 \\
18.27 \\
21.28 \\
23.94 \\
27.09 \\
30.46 \\
33.97\end{array}$ & $\begin{array}{r}0.38 \\
0.85 \\
1.51 \\
2.27 \\
2.93 \\
3.73 \\
5.29 \\
7.50 \\
7.98 \\
9.56 \\
11.81 \\
13.70 \\
16.08 \\
18.37 \\
21.36 \\
24.01 \\
27.16 \\
30.53 \\
34.04\end{array}$ & $\begin{array}{r}.40 \\
.67 \\
1.05 \\
1.87 \\
2.96 \\
3.78 \\
5.16 \\
6.37 \\
8.08 \\
9.65 \\
11.68 \\
13.70 \\
15.95 \\
18.43 \\
21.12 \\
24.04 \\
26.77 \\
30.57 \\
33.94\end{array}$ \\
\hline
\end{tabular}

It should be explained that the timber included in the above study contained a considerable amount of black spruce in the lower diameter classes too small to be economically utilized as lumber. On the basis of the above study, and in consideration of other factors involved, it was decided that trees up to and including 9 inches D.B.H. should be put into pulpwood, and that trees over 9 inches D.B.H. should be made into lumber. The utilization of tops below 8 inches in diameter as lumber or as pulpwood was made optional with the operator under the timber sale agreement.

As mentioned earlier, there can be no single clear-cut answer to the question, "In any integration of forest industries, what is the dividing line in the allocation of softwoods as sawlogs and pulpwood material?" satisfactorily applicable to all areas and conditions. Each stand, concession, or area must be judged largely on its own merits. In seeking an answer for individual areas I would list the different variables to be considered as follows: 
1. Composition of Stand - Under this heading we must consider first of all what timber should be removed and what timber should be left. Of the timber to be removed we must consider diameter class distribution. Is it primarily a pulpwood proposition, or primarily a sawlog proposition? Is there a sufficient volume of each, and is it so distributed as to make an integrated operation possible? If the sawlog material was removed, could the pulpwood remaining be removed economically in a second operation, perhaps in conjunction with pulpwood on an adjoining area? In borderline cases, would the raising or lowering of the "dividing line diameter" tentatively used for the purpose of study assist in making an integrated operation more practical.

2. Utilization, Marketability, and Prices - If we consider utilization only, that is "maximum utilization of the raw material in trees to be removed", which of course is a worthy objective, then all trees should obviously be put into pulpwood. This, of course, would not do, as such a procedure would not supply us with what we want, and for the present at least utilization in some degree must be sacrificed in order to provide our other requirements. If we do not place too high a value on sawmill waste, this can be done on a sound economic basis, depending largely on price of product. The factor to consider here is, what return will we get on the timber we have under consideration if the same is converted into pulpwood, and what return will we get if the same is converted into lumber, or would we get even a better return if the timber in question were converted partly into lumber and partly into pulpwood? From the point of view of provincial or national economy we may have to consider, for instance, whether the timber, if produced as pulpwood, is for export as pulpwood, or whether it will be manufactured into paper or some other finished product within the province. It is obviously poor economy to convert saw timber into pulpwood and sell it at $\$ 12.00$ per cord for export, when the same timber, if made into lumber, would bring a return several times greater. On the other hand, if the pulpwood is to be made locally into newsprint, for instance, with an end value approximating $\$ 90.00$ and upwards per cord, a return several times higher than if made into lumber, it would seem to be economically desirable that the same be made into pulpwood.

3. Stumpage Values - Stumpage in large measure must pay for the cost of forestry, and stumpage return, therefore, is an important factor. On the basis of timber dues presently in effect in Manitoba, $\$ 4.00$ per thousand for lumber $\$ 1.50$ per cord for pulpwood, it will be seen from Table No. II that trees 9 inches and over will give a greater return in stumpage if made into lumber than if made into pulpwood, notwithstanding waste of valuable material in manufacture, while the opposite is true of trees less than 9 inches D.B.H. On trees 9 inches and over the difference in stumpage return on lumber as against the stumpage return on pulpwood increases progressively and proportionately with tree diameter. The stumpage return on a 10-inch tree, for instance, is $23 \mathrm{c}$. and $25 \mathrm{c}$. for pulpwood 
and lumber respectively; on a 15 -inch tree 61c. and $84 \mathrm{c}$. respectively; on a 24-inch tree $\$ 1.84$ and $\$ 3.02$ respectively.

From the point of view of stumpage return we are faced with two alternatives: (a) Require that all trees 9 inches and over D.B.H. be utilized as sawlogs, and under 9 inches D.B.H. as pulpwood; or (b) Adjust the stumpage rate for pulpwood upwards for trees in the higher diameter classes. For reasons which may be peculiar to Manitoba we have, as far as possible, adopted alternative (a). However, it is true that we still have too many instances where sawlogs are being made into pulpwood, and pulpwood being made into sawlogs, partly for the reason that industry has not yet fully adopted itself to integrated operations.

4. Accessibility and Exploitation Facilities - Any integrated operation must be considered from the point of view of cost of operation. We must consider whether it will pay an operator to put in the necessary equipment, etc., to handle both sawlogs and pulpwood. We must consider what procedure is necessary in keeping one product separate from the other, what facilities are available or can be established for sorting, or must the two products be kept separate and handled separately from start to finish. The simplest set-up would appear to be an operation where timber is waterborne to a central point where it could be sorted as to diameter, allocated and readily distributed. The timber in this instance would be cut to sawlog lengths and handled as a single operation until the central point is reached. The ease with which sawlogs and pulpwood can be separated, one from the other, may often determine whether or not an integrated operation is economically practical.

TABLE NO. III

Tabulation showing various forms of utilization of an estimated $1,550,571 \mathrm{cu}$. $\mathrm{ft}$. of black and white spruce on an area under consideration for a timber sale in Manitoba-Townships 45 and 46 , range 26 W.P.M.-based on disposal of merchantable white spruce to a stump diameter of $12^{\prime \prime}$ and merchantable black spruce to a stump diameter of $7 "$-lumber (rough) $\$ 45.00$ per M.F.B.M., pulpwood $\$ 12.00$ per cord F.O.B. car at rail head-stumpage lumber $\$ 4.00$ per M.F.B.M., pulpwood $\$ 12.00$ per cord.

\begin{tabular}{|c|c|c|c|c|c|c|}
\hline \multirow{2}{*}{ Product } & \multirow{2}{*}{$\begin{array}{l}\text { M.F.B.M. } \\
\text { Int'l. L.R. } \\
\text { 1/1/K. }\end{array}$} & \multirow{2}{*}{$\begin{array}{l}\text { Pulpwood } \\
\text { Cords }\end{array}$} & \multicolumn{2}{|c|}{ Utilization } & \multirow{2}{*}{ Sale Value } & \multirow{2}{*}{ Stumpage Valoe } \\
\hline & & & Cu. Ft. & $\%$ & & \\
\hline $\begin{array}{l}\text { As lumber only to } 5^{\prime \prime} \text { top } \\
\text { As pulpwood only to }\end{array}$ & 4,217 & - & 351,427 & 22.6 & $\$ 189,765.00$ & $\$ 16,868.00$ \\
\hline $\begin{array}{l}\text { top diameter } 3^{\prime \prime} \\
\text { As lumber to top dia- }\end{array}$ & {[} & 13,963 & $1,330,959$ & 86 & $\$ 167,556.00$ & $\$ 20,944.50$ \\
\hline $\begin{array}{l}\text { meter } 7^{\prime \prime} \text { to } 8^{\prime \prime}- \\
\text { Balance to } 3^{\prime \prime} \text { as pulp- } \\
\text { wood }\end{array}$ & 3,273 & 7,409 & 813,637 & 52.5 & $\$ 236,193: 00$ & $\$ 24,205.50$ \\
\hline
\end{tabular}


In conclusion, may I say again that no single, clear-cut answer can be given which would be satisfactorily applicable to all areas under all conditions. So many variables are involved that each individual stand, area, or concession must be judged largely upon its own merits. The elimination or reduction within reasonable bounds of waste in the woods can be achieved in integrated operations. Lumber and pulpwood operations must dove-tail so that the timber is put to its best economic use with a minimum of waste. Ways and means which will permit of economic extraction must be found and developed. In the allocation of softwoods for sawlogs and pulpwood material, other factors being equal, I suggest that we cannot afford to tolerate indefinitely logging practices and methods which result in the utilization of less than one-third of the raw material contained in the trees which, under sound forestry practices, should be removed. I also suggest that where utilization of trees of sawlog size as pulpwood will bring a greater return to the national economy than utilization as lumber, and at the same time provide more complete utilization of the raw material found in the forest, making for better forest management, and provided our other requirements are satisfactorily met, there can be no very good reason why the same should not be put into pulpwood.

In this paper I have dealt only with spruce, feeling that my references to this species apply fundamentally to other softwoods. While species and conditions vary greatly across the Dominion the basic problems are the same. 